\title{
Pacific (2018)
}

\author{
W.John Hopkins*
}

The Pacific region is one that defies both easy definition and superlatives. Given that this is the first of regular annual Pacific updates on International Disaster Law it is important to provide readers with both a clear definition of its scope and an overview of the region itself. Definitions of the Pacific 'region' vary dramatically, depending upon the geographical location of the person concerned. In the United States, for example, such a definition will usually encompass the nation-States of the Pacific Rim, including Japan and Korea and tend to ignore those States situated within the Pacific Ocean itself. Such selective blindness is also often seen in international documents, which while claiming to discuss the 'Asia-Pacific', tend to focus on the Asian rather than the Pacific element. For the purposes of this section, however, the definition will be limited to those States and territories within the Oceanic Pacific. For practical purposes this includes the Full and Associate members of the Pacific Island Forum (PIF) and those Pacific Island members of the South Pacific Community (SPC). ${ }^{1}$

However, even though the Pacific is classified as a region by the United Nations and operates a regional platform under the UNISDR, ${ }^{2}$ it is often treated as something of an 'add-on' to Asia. For example, the UNISDR operates a regional office for Asia and the Pacific, which is based in Thailand (although a subregional office operates in Suva, Fiji). To give one some conception of the

* Professor of Law, Law School, University of Canterbury. The author wishes to thank Julia Hartelius (Regional Coordinator, Asia Pacific, IFRC) and Finau Leveni for their assistance in preparing this report. Any errors or omissions are the fault of the author.

1 The Pacific Island Forum countries are Australia, Cook Islands, Fiji, French Polynesia (Fr), Kiribati, Marshall Islands, Micronesia, Nauru, New Caledonia (Fr), New Zealand, Niue, Palau, Papua New Guinea, Samoa, Solomon Islands, Tonga, Tuvalu and Vanuatu. Tokelau (NZ) is an Associate Member. In addition to the PIF member States, the SPC memberships include the following Pacific island territories; American Samoa (US), Guam (US), Northern Mariana (US) Islands, Pitcairn Islands (UK) and Wallis and Futuna (Fr). The Cook Islands and Niue have free association agreements with New Zealand, which means that their citizens are citizens of New Zealand and New Zealand has a degree of responsibility for foreign affairs and defence.

2 See <https://www.unisdr.org/we/coordinate/regional-platforms $>$, last accessed (as any sube sequent URL) on 29 June 2019. 
difficulties this presents, it is important to remember that the distance from Bangkok to Papeete (the capital of French Polynesia) is 12,500 kms. By comparison, the distance from Bangkok to London is 9,500 kms. In addition to the tyranny of distance (Palau and Papeete are nearly 9,00o kms apart), the PIF covers eleven time zones (including crossing the dateline) and has a combined Exclusive Economic Zone larger than the land mass of Africa. The immense scale of the Pacific means that regarding the Pacific as a region is problematic such are the cultural, linguistic and geographic divisions that lie within it. Yet for reasons that are external to the Pacific, the international community continues to persevere with this concept, something the Island States themselves understand and tolerate, if not embrace wholeheartedly.

In addition to these spatial divisions, the Pacific region is divided by economic inequality and the long shadow of its colonial history. While two States (Australia and New Zealand) are wealthy OECD members with controversial colonial pasts, all other members of the Pacific Forum are classed as Small Island Developing States, ${ }^{3}$ most of which suffered from appalling treatment during the colonial era. ${ }^{4}$ The lack of development in the Oceanic Pacific also has a practical impact upon the region's integration and its co-operation with the international community as travel between the states is difficult and expensive. Despite these hurdles, a weak form of pan-regional architecture does exist, based around two regional organisations, the Pacific Islands Forum (PIF) and the (South) Pacific Community (SPC). ${ }^{5}$

Both these organisations have played a notable if limited role in regional disaster risk reduction (DRR). The SPC is a scientific and technical body that supports development in the Pacific region. Funded by development partners, it is owned by its 26 member States (including non-Pacific states such as the US and France) and has a broad remit to offer scientific and technical assistance to member states including in the fields of climate change and disasters (amongst many others). The PIF, by contrast, is a political body, without formal status, although the PIF Secretariat play an important co-ordinating role in the region. In particular, it plays the primary organisational role in the CROP (Council of Regional Organisations of the Pacific) of which the SPC is one.

In recent years, the PIF in particular has provided a space for increased co-operation in the field of Disaster Law, notably through The Framework for

3 The Cook Islands is scheduled to be recognised as a developed state by the OECD in 2019.

4 Many of these impacts have significant cultural and economic impacts today. See for, example, the practice of 'Blackbirding', the kidnapping of Pacific islanders to work as slaves in Australia and South America, which continued into the early twentieth century.

5 The South Pacific Community retains its formal name and old acronym but now brands itself as the Pacific Community. 
Resilient Development in the Pacific 2017-30 (FRDP). This is all the more relevant as, in addition to its economic and geographic challenges, the Pacific region has the highest level of natural hazard and risk globally. Nevertheless, despite these developments, engagement with international Disaster Law remains limited in the region due to the political, geographic and economic challenges that continue to undermine co-operation. Despite this history of limited co-operation, the Pacific has shown a newfound vigour in recent years driven particularly by the increasing level of hazards experienced and the potentially catastrophic impact of climate change on the region.

At the regional level, 2018 saw the PIF begin to implement its 2017 commitment to the Blue Pacific identity. This is an attempt to re-invigorate the Island States' commitment to regionalism through a recognition of the Oceanic nature of the region and breathe new life into the 2014 Framework for Pacific Regionalism. 2018 saw this gain traction through the Boe declaration on Regional Security. This document built upon previous declarations of security, which had provided the PIF with a very limited mandate in the field of disaster management. These can be traced to the Aituktaki declaration of 1997 which, although driven by metropolitan state ${ }^{6}$ priorities around instability, did include a broader reference to 'the immediate risks to security in the region (...) including natural disasters, trans-national crime including drug trafficking, and economic, social and environmental policies.' ${ }^{7}$ The Boe declaration builds upon the commitments and principles of intervention agreed at Biketawa ${ }^{8}$ and further expands the concept of security to include explicit reference to, and a commitment to an increasing emphasis on 'humanitarian assistance.' ${ }^{9}$ In addition, the preamble makes specific reference to importance of climate change and links the declaration to the global priorities agreed at the Paris

6 Australia and New Zealand are collectively referred to as the 'metropolitan States' in a Pacific regional context.

7 Pacific Islands Forum, 'Aitutaki Declaration on Regional Security Cooperation' (18 September 1997), available at <https://www.forumsec.org/aitutaki-declaration-on-regional-security -cooperation>.

8 Pacific Islands Forum, 'Biketawa Declaration' (28 October 2000), available at $<$ https://www .forumsec.org/biketawa-declaration>.

9 Pacific Islands Forum, 'Boe Declaration on Regional Security' (5 September 2018), available at $<$ https://www.forumsec.org/boe-declaration-on-regional-security>, para. vii. 
Agreement. ${ }^{10}$ This provides a specific regional mandate in the field, which has previously been lacking. Furthermore, the parties 'commit to the strengthening the existing regional security architecture inclusive of (...) regional organisations' ${ }^{\prime 1}$ in accordance with the new definition. In practice this will require the Council of Regional Organisations of the Pacific (СROP), including the SPC, to:

- account for the expanded concept of security,

- identify and address emerging security challenges,

- improve coordination among existing security mechanisms,

- facilitate open dialogue and strengthened information sharing,

- further develop early warning mechanisms,

- support implementation,

- promote regional security analysis, assessment and advice, and

- engage and cooperate, where appropriate, with international organisations, partners and other relevant stakeholders. ${ }^{12}$

Although the extent to which this will make an impact on the operation of the agencies themselves in the field of DRR remains open to debate, 2018 has the potential to be a defining moment for Pacific approaches to DRR. With the PIF specifically recognising a mandate to develop (and focus) upon the wider conceptions of security recognised by the Boe declaration, including disaster risk reduction, Pacific Island States seem more willing to explore deeper cooperation in a field where they have traditionally been reluctant to do so, given their strong views on national sovereignty. This has the potential to bring about a step-change in co-operation around regional DRR. Given the current lack of formalised co-operation, this should be strongly welcomed.

Nevertheless, the emergence of a greater willingness on the part of the PIF states to co-operate in their approach to DRR, should be tempered by the continued commitment within the Boe declaration to 'respect and assert the sovereign right of every Member to conduct its national affairs free of external interference and coercion..$^{13}$ This reflects a continued reluctance on the part of PIF states to embrace regional co-operation fully. This reluctance reflects both the difficulties in managing the Pacific as a 'region', which exists more in the minds of development partners, desperate to talk to one regional voice rather than eighteen (or more), and the continued fear of Pacific states that such commitments to co-operate may be used by the metropolitan states as the

\footnotetext{
$10 \quad$ Ibid., paras. i and vii.

11 Ibid., para. ix.

12 Ibid.

13 Ibid., para. iv.
} 
basis for unwanted intervention. It therefore remains to be seen whether practical efforts will reflect the new-found PIF commitment to DRR.

\section{$3 \quad$ Other Regional Developments}

Although the Boe declaration was the most significant regional political/legal development in the Pacific in 2018, a number of other initiatives are also worthy of note both at the regional and global levels. In the field of Health, 2018 saw the launch of the WHo's Pacific Islands Action Plan on Climate Change and Health as part of the wHo Special initiative on Climate Change and Health in Small Island Developing States (SIDS) launched in 2017..$^{14}$ This document aims to provide a roadmap for the development of resilient health care systems capable of adapting to increased pressures of climate change related diseases and health outcomes.

In addition, 2018 saw further developments towards the creation of a regional agreement around resilience and climate change funding. In April the Forum Economic Ministers Meeting (FEMM) considered proposals for the creation of a regional resilience funding facility (led by the Cook Islands, Fiji, New Zealand, Palau and Samoa) and a Climate Change Insurance Facility (PICCF) (led by Tuvalu). The latter is now supported by a taskforce which has met several times in 2018. The PICCIF initiative (launched in 2017) aims to develop insurance and other financial instruments to complement the existing Pacific Catastrophe Risk Assessment and Financing Initiative (PCRAFI) which incorporates financial support mechanisms. The aim is to produce a system capable of funding 'sudden onset adaptation events' where a community is forced to adapt in a permanent way. By working with insurance and other financial mechanisms the PICCIF aims to improve financial resilience to the effects of climate change in a Pacific context. ${ }^{15}$

\section{$4 \quad$ National Developments}

The lack of regional co-operation in the field should not blind us to the fact that disaster law remains an active and developing area of law in many Pacific

14 wно, 'Pacific Islands Action Plan on Climate Change and Health' (2018), available at $<$ https://apps.who.int/iris/handle/10665/275484>.

15 See <https://www.forumsec.org/forum-economic-finance-ministers-look-pacific-resil ience/ $/$. 
nation states. This was as true in 2018 as in any other year. The key driver of these developments, internationally, is not the PIF or the SPC but the International Federation of the Red Cross (IFRC), which has played a de facto role in developing co-operation across the region.

In 2018, this saw a number of domestic developments closely linked to the emerging international disaster law framework. In particular, January saw Samoa endorse a new Natural Disaster Management Plan (NDMP) for 2017-2020. The new plan (which replaced the 2011-2014 iteration), is more focussed and ambitious than its predecessor and reflects both lessons learnt from the 2009 tsunami and Cyclone Evan (2012). ${ }^{16}$ These reforms include improved mechanisms around international aid, specific recognition of the Red Cross as the lead NGO and a recognition of gender and disability equality as fundamental to disaster risk management (DRM).

The processes around international assistance are of particular note with implementation of a clear chain of authority requiring all requests to be channelled through the National Disaster Council. ${ }^{17}$ Such requests must follow the relevant Standard Operations Procedures contained in the NDMP..$^{18}$ Although the plan does not establish a 'one stop shop' model it does provide the National Emergency Operation Centre with the clear responsibility for liaison with Customs, Agricultural and Fisheries personnel to ensure clearance for disaster relief assistance. In addition, the NEOC is explicitly charged with the distribution of such aid (under the overall management of the Disaster Advisory Committee).${ }^{19}$ This is a significant advance on previous arrangements and provides something of a best practice model amongst Pacific Islands states. The NDMP should be seen as part of a wider DRR policy drive in Samoa, which includes the National Action Plan (NAP) for DRM (2017-2021), also approved in 2018. The NAP is tied closely to the Sendai process but, in line with Pacific Priorities and the Framework for Resilient Development in the Pacific (FRDP), attempts to co-ordinate Samoan responses to the needs of DRM and climate change.

Other domestic developments also show evidence of strong regional cooperation, again facilitated by the IFRC and national Red Cross Societies. The decision by the Fiji government to review the Fijian DRM Act and the Fijian

16 Government of Samoa, 'National Disaster Management Plan 2017-2020' (2018), available at <https://www.mnre.gov.ws/wp-content/uploads/2017/08/Samoa-national-disaster -management-plan-2017-2020-final-web.pdf>.

17 Ibid., Part 2, Section 3.31.

18 Ibid., Appendix 7.

19 Ibid., Part 2, Section 3.3. The DAC comprises representatives from government agencies, NGOS, the private sector and development partners. 
NDMP in conjunction with the IFRC is further evidence of this, as is the IFRC facilitated peer-learning programme with Vanuatu, which also took place in 2018. Micronesia, the Marshall Islands, Tuvalu, Vanuatu and Tonga are all in the process of reviewing their legislative and policy frameworks against the IDRL guidelines. Tokelau is looking to develop a similar act and policy framework, again incorporating the IDRL guidelines.

Nevertheless, this activity in the field of formal disaster law in the South Pacific in 2018 should not obscure the fundamental difficulties that such Eurocentric mechanisms can have in societies where the legal system is a complex mix of customary law and European style state-based regulation. In the 2018 IFRC report into cyclone Gita, the problem of ensuring 'proper' procurement processes in Tonga was raised as a significant issue. ${ }^{20}$ Given the nature of the Tongan legal system one can also raise the alternative view that procurement policies appropriate to a fully functional 'western' legal order may not be suitable in a Pacific Island situation, particularly in the midst of a disaster. This raises the long-standing concern that international disaster law remains a creature of the western world and is applied to, rather than with, those who suffer most from large-scale disasters.

\section{5}

Conclusions: 2018 an Important Year for Pacific Disaster Law

2018 was an important year for the Pacific region in the field of disaster law, with the Boe declaration marking a firm commitment to enhanced regional co-operation within the framework of the 'Blue Pacific' identity. Alongside this, PIF members have shown increased interest in the potential for regional co-operation in the field as shown by the ASEAN example (after an IF RC facilitated peer-learning visit in 2017). A concrete example of this has been the support shown by the PIF member states to map their individual DRM policies and law against international best practice (in the form of the IDRL guidelines). 2019 promises to see greater progress in the field with the PIF, alongside the SPC and the IFRC, prioritising improved legislative frameworks for DRR within the framework of the Framework for Resilient Development in the Pacific. Nevertheless, although the increased interest in the Pacific in DRM both domestically and internationally is to be welcomed it remains an open question as to how far these developments will reflect the needs of the Pacific itself rather than the priorities of its richer members and development partners.

$20 \quad$ IFRC, 'Emergency Plan of Action Final Report - Tonga: Cyclone Gita' (2018). 